Krzysztof Gawlikowski

\title{
CHINY W OPISACH PODRÓŻNIKÓW ARABSKICH
}

Wspanialy świat Oceanu Indyjskiego Sulajmana Kupca, Abu Zajda as-Sirafiego i Buzurga Ibn Sahrijara. Od literatury faktu do przygody $i$ fantastyki (IX-X w.). Przełożył z arabskiego, wstępem i komentarzem opatrzył Andrzej Za-barski, Księgarnia Akademicka, Kraków 1998, str. 200.

Książka ta udostepnia czytelnikowi polskiemu najstarsze zachowane teksty arabskie opisujące Indie, kraje Azji Południowo-wschodniej oraz Chiny, którym poświęca się tam bardzo wiele miejsca. Są one tym bardziej ciekawe, iż autorami ich są ludzie z kręgu cywilizacji arabskiej, wówczas niewątpliwie górującej nad krajami europejskimi. Choć przyzwyczailiśmy się traktować ją jako przynależną do „Orientu", to pamiętać trzeba, że cywilizacja ta formowała się na wschodnich obrzeżach świata śródziemnomorskiego, z którego dorobku szeroko korzystała i z jakim dzieliła wiele z fundamentalnych idei. Dość przypomnieć, że islam jest religią podobnego rodzaju jak mozaizm i chrześcijaństwo, czci tego samego Boga-Stwórcę, Abrahama, Mojżesza oraz Jezusa (choć uznaje go tylko za jednego z proroków), zna anioły i Szatana, ma swój „dzień święty" w siedmiodniowym tygodniu, przywiązuje wielkie znaczenie do Prawa, itd. Świat arabski przechował też wiele dzieł starożytnych autorów greckich i rzymskich, zaginionych na Zachodzie. Zatem obserwator $\mathrm{z}$ tego kręgu kulturowego był w Azji Wschodniej, różniącej się w sposób fundamentalny — „człowiekiem Zachodu".

Najstarszy $\mathrm{z}$ przełożonych tu tekstów Opis Chin oraz Indii (s. 33-63), przypisywany kupcowi o imieniu Sulajman, zawiera dane o Chinach $\mathrm{z}$ odnoszące się do pierwszej połowy IX w. Drugi tekst Dodatek o Chinach i Indiach (s. 65-97) jest cokolwiek późniejszy, gdyż wspomina o wojnach 
rami z dużą liczbą ozdobnych grzebieni), zaś mężczyźni miast turbanów noszą rodzaj mycki (raczej małej czapeczki). Autor Dodatku odnotowuje, iż Chińczycy nie oddają moczu kucając, jak na Bliskim Wschodzie, lecz stojąc, co uznają za zdrowsze, ponadto zaś opisuje zwyczaj używania do tego celu przez bogatszych ,drewnianych rur malowanych" (zapewne bambusowych), aby nie brudzić szat (s. 82-3).

W obydwu tekstach pojawia się wątek ukazywania Chin jako czołowego mocarstwa świata, choć w specyficznym kontekście. Autor Opisu podaje, iż mieszkańcy Chin oraz Indii uznają czterech władców za najbardziej liczących się w świecie. „Pierwszym jest władca Arabów, według nich najpotężniejszy, najbogatszy i najwspanialszy, przywódca wiernych wyznających największą religię, nad którą na świecie nic większego nie ma". Dopiero drugie miejsce zajmować ma władca Chin, za nim zaś idą władcy Bizancjum i Indii (s. 47). W Dodatku znajdujemy natomiast fikcyjny dialog z cesarzem chińskim, w którym ten stawia na pierwszym miejscu „władcę Iraku", który „w samym środku świata leży", siebie wymienia na drugim, dalej władcę „dzikich bestii czyli Turków", władcę Indii ,z jakich wszelka mądrość pochodzi", oraz Bizancjum, w jakim są „najlepiej zbudowani i najpiękniejsi mężczyźni" (s. 71-2). Jest to dobry przykład, jak rozmaite wiadomości są adaptowane do wymagań czytelnika arabskiego. Istotnie w Chinach mówiło się o ,władcach czterech stron świata", lecz odnosiło się to do „wasali" cesarza chińskiego, Syna Nieba i zwierzchnika Krainy Środka, traktowanego jako ich naturalnego zwierzchnika. Tu zaś Krainę Środka lokuje się w Iraku, prym przyznając Arabom, ale innych władców traktuje się jako suwerenów. Oczywiście Chińczycy nie mogli by też tak wysokiej lokaty przyznawać Turkom i Bizancjum, ani uznawać Indie za źródło mądrości. Mamy tu zatem do czynienia z przejawem jaskrawego ,arabocentryzmu" i przypisywania Chińczykom poglądów, jakich mieć nie mogli. Odnotować jednak trzeba, że władcę Chin stawia się nieodmiennie na drugim miejscu, autorzy zdają więc sobie sprawę z ogromu i potęgi tego kraju.

Dodajmy, iż autor pierwszego tekstu wspomina, że ma tam być dwieście wielkich miast, co wydaje mu się liczbą ogromną, a Kanton jest tylko jednym z nich. Podobnych wiadomości tylko po części prawdziwych jest wiele. Autor wspomina, na przykład, obyczaj podawania czasu w mieście przy użyciu wielkich trąb i bębnów, podczas gdy tylko te drugie były używane do tego celu.

Zwraca uwagę na „praworządność" i uczciwość urzędników, którzy — na przykład - korzystając z prawa pierwokupu przywiezionych towarów przez skarb, płacą za nie cenę wyższą od rynkowej. Pisze dość obszernie, choć nieściśle, o sprawności systemu administracyjnego i prawie każdego $\mathrm{z}$ poddanych do składania skarg, czy przedkładania władzom swych 
spraw. Zaskakuje go, iż we wszystkich kontaktach z władzami obywatele zwracać się do nich muszą na piśmie, i to w formie dokumentu o prawidłowej formie, za jaką odpowiada funkcjonariusz przyjmujący go. Rozwinięte zarządzanie przy pomocy profesjonalnego aparatu biurokratycznego i wieloszczeblowych instytucji „nowoczesnego państwa" jest autorowi, w sposób oczywisty, nieznane.

Wspomnijmy, iż wysokie świadectwo wystawia on szkolnictwu powszechnemu, istotnie rozwijanemu w epoce Tang, pisząc, iż wszyscy, biedni i bogaci, dorośli i dzieci, pisać się tam uczą (s. 53), a skarb opłaca nauczyciela w szkole znajdującej się w każdym mieście dla dzieci z rodzin ubogich (s. 57). Wprawdzie przy skomplikowanym systemie pisma analfabetów musiało być wielu, ale odnotować te informację warto, gdyż potwierdza dość powszechne opanowanie w Chinach sztuki pisania i czytania. Zdumiewa go również konieczność posiadania, tak przez Chińczyków jak i cudzoziemców, dokumentów potwierdzających tożsamość danej osoby, jak też konieczność wpisywania potomków męskich do administracyjnych rejestrów ludności.

Podobnie zaskakuje go precyzyjny system wydawania przez funkcjonariuszy państwowych potwierdzeń ilości przewożonych towarów oraz pieniędzy, kontrolowanych następnie po drodze, by łatwo ustalić miejsce kradzieży, czy - w razie śmierci w podróży — zabezpieczyć przekazanie ich spadkobiercom (s. 55). Dodać do tego jednak trzeba, że nie tylko tak szlachetne cele temu przyświecały, lecz i konieczność opłacania myta, a wiązało sie to także $\mathrm{z}$ nadzorem państwa nad działalnościa gospodarcza oraz kontrolą nad kupcami. Przewóz znaczniejszych sum pieniężnych był, rzecz jasna problemem, dopóty dopóki w kilka stuleci później nie wymyślono w Chinach obsługi bankowej. Autor odnotowuje również, że władze przez system państwowych zakupów żywności w okresie (i w miejscu) urodzaju, a sprzedawania ich z magazynów w okresie niedoboru, zapobiegają drożyźnie (oraz — dodajmy — stabilizują rynek produktów rolnych, kluczowy w państwie agrarnym). W Chinach system ten wprowadzono jeszcze w starożytności, choć z jego właściwym funkcjonowaniem stale były trudności nie mniejsze niż we współczesnej Polsce, która go stosuje nie wiedząc nawet o jego chińskim rodowodzie.

Autor błędnie pisze o stosowaniu w Chinach tylko podatku pogłównego, choć związanego z zamożnością, ale za to trafnie wskazuje na posługiwanie się w obrocie codziennym monetami miedzianymi, ewentualnie nanizanymi na sznurek przy większych płatnościach, a tylko w dużych transakcjach (i przy płatnościach skarbowych) — srebrem.

Jako kupiec odnotowuje $\mathrm{z}$ wielką satysfakcją państwowy nadzór nad ogłaszaniem bankructwa firmy i ścisłe reguły zabezpieczania interesów wierzycieli, podobnie jak ogromną uczciwość w interesach oraz przy spła- cie długów, zawsze potwierdzanych stosowna umowa na piśmie, w dwu egzemplarzach, z potwierdzaniem jej przez wierzyciela odciskiem swojego palca (zwróćmy uwagę, iż wiązało się to z rozwojem daktyloskopii!). Choć z pewnymi zafałszowaniami, autor odnotowuje też istnienie w Chinach państwowej kontroli służby medycznej, nie doszła jednak ona do poziomu pokrywania kosztów medykamentów dla uboższych przez skarb, co bezpodstawnie Chinom przypisuje, choć istotnie były rozmaite systemy oparte na pomocy wspólnot lokalnych. Pojawiają się zatem tak charakterystyczne przy opisach Chin elementy ich idealizacji (czemu ulegali i dawni autorzy europejscy).

Zdumiewa również Sulajmana, iż cesarza lud rzadko tylko oglądać może (raz na dziesięć miesięcy — jak pisze), podczas gdy w istocie nigdy go nie mógł widzieć. Przytacza też jego rzekome wypowiedzi: „Ludzie jęli by mnie lekceważyć, gdyby ciągle mnie widzieli"; „Autorytet buduje się tylko okazując ludowi pychę i pogardę, bo lud, co znaczy porządne traktowanie, nie wie i, żeby nas szanował, wyniośle i lekceważąco traktować go trzeba" (s. 54). Oczywiście żaden Chińczyk takich stwierdzeń jakiemuś Arabowi cytować nie mógł, gdyż wszystkich — z władcą na czele — obowiązywała zasada skromności, czy wręcz uniżoności, a władca musiał wręcz okazywać szacunek ludowi i deklarować nieustanna prace dla jego dobra. Jednakże autor odnotowuje trafnie, iż stosunki ludu i władcy są tam zupełnie inne niż w jego świecie śródziemnomorskim, a władze cieszą się o wiele większym respektem.

Autor Dodatku, uzasadniając drugą pozycję Chin w świecie, cytuje następującą wypowiedź przypisywaną cesarzowi (choć jej forma temu zaprzecza): „Po nim (to jest władcy Iraku) jest nasz władca, którego prawdziwym władcą swych poddanych nazywamy, jako że nikt lepiej od niego państwem i ludem nie rządzi, porządku nikt lepiej nie pilnuje i nigdzie poddani nie są tak jak u nas posłuszni" (s. 71-2). Obserwacje odnoszące się do stosunku do władz, i to obserwatorów z kręu kultury arabskiej, zasługuja na szczególną uwage, gdyż pokazuja, iż nawet $\mathrm{w}$ despotycznych państwach Bliskiego Wschodu stosunki władcy z poddanymi przedstawiały się inaczej.

Autor Dodatku opisuje szczegółowo sposób przejazdu wysokich dostojników i usuwanie się z ulic ludności oraz zamykanie w domach na ten czas. „Na drogach nikt nie zostaje, bo wszystkich strach przepędza. A wszystko to po to, żeby lud tylko $\mathrm{z}$ rzadka dostojników widywał i niczego powiedzieć im nie mógł", s. 69). Oczywiście objaśnienie to nie w pełni jest prawdziwe, gdyż o rozmaite względy chodziło, ale zwyczaj ten, związany $\mathrm{z}$ nimbem tajemniczości otaczającym władze, opisany jest wiernie.

Zasługuje na uwagę, iż przy opisie Indii wspomina się o wojnach między państwami, w Chinach zaś tylko o buntach wstrząsających niekiedy cesarstwem, co oczywiście odpowiadało ówczesnym realiom politycznym 
(s. 59-60). Kilkakroć pojawiają się też wzmianki o kanibalizmie w Chinach. O losie buntowników Sulajman pisze: „Wtedy gardło mu podrzynają i zjadają, albowiem Chińczycy jedzą mięso tych, którzy od miecza zginęli" (s. 60). Autor Dodatku idzie jeszcze dalej: „Jeśli jeden (z buntowniczych zwierzchników prowincji - K.G.) w siłę obrósłszy drugiego pokonał, wtedy prowincję jego zabierał, niszczył co tylko tam było, wszystkich zaś mieszkańców zjadał - jako że prawo ich na to pozwala i mięso ludzkie u nich nawet na targowiskach sprzedaja" (s. 67). Jak widać przedstawianie Chin tak, by budziły one zgroze, ma swoich antenatów już w czasach odległych (podboje służyły przecież zwiększaniu liczby płatników podatków, a z kogóż administrator zbierałby podatki, gdyby najpierw „,wszystkich mieszkańców" nowych terytoriów zjadł, co przy wielomilionowej ludności wymagałoby brzucha większego niż u Lewiatana!)

$\mathrm{Na}$ dobro autorów arabskich zapisać jednak należy, iż — inaczej niż niektórzy współcześni nam dziennikarze - gromadzili oni tak informacje negatywne, jak i pozytywne starając się je jakoś równoważyć. Autor arabski przypisuje bowiem tę dramatyczną sytuację czasom chaosu, a według niego poprzednio Chińczycy „w państwie tak praworządnym żyli, iż nikt nigdy o podobnym nie słyszał" (s. 79). Nie jest jasne skąd takie opowieści o masowym kanibalizmie brać się mogły. Być może związane są one $\mathrm{z}$ istotnie spotykanymi tam niekiedy praktykami rytualnego zjadania kawałków serca, lub wątroby, pokonanego wroga. Praktykowali to jeszcze żołnierze armii Południowego Wietnamu w latach siedemdziesiątych XX w., więc w Kantonie, bliższym kulturowo ludom Vietu, opowieści o tym mogły. krążyć. Wspomnieć można, że pierwszą ofiarą powstania „bokserów" w Pekinie był Sugiyama, sekretarz poselstwa japońskiego, jaki zginął dla przeprowadzenia takiego właśnie prastarego rytuału. Mordowanie podróżnych w odludnych karczmach, i serwowanie dań z nich przyrządzonych następnym gościom, jest częstym wątkiem w średniowiecznych opowieściach chińskich, choć zdaje się to być przede wszystkim motywem literackim, mało mającym wspólnego z rzeczywistością. Niewątpliwie buddyzm, z jego ideą jedności świata istot żywych nie oddzielał tak człowieka od zwierząt, jak to było w śródziemnomorskich religiach objawionych, co kształtowało inny stosunek do ciała ludzkiego. Bardziej jednak prawdopodobne jest, iż wieści te pochodzić mogły z błędu tłumaczy. Otóż po chiński czasownik ,jeść", czy „zjadać" (chi), ma o wiele szersze znaczenie i oznacza także „likwidować", „uciskać". Stąd sztony w grach podobnych do szachów „zjada się" nie zaś „zbija". Bogacz, czy urzędnik uciskający lud „zjada go", podobnie jak zdobywca nowe krainy. Ktoś coś usłyszał, nie zrozumiał, i oto „czarna legenda" gotowa! Podobnego typu bzdury o Chinach wypisują nieraz i współcześni dziennikarze, a specjalista dobrze nagłowić się musi, jak dany autor coś takiego mógł wykoncypować.
Takie opisy „okropieństw" są zresztą częstym elementem w opisach tak dawniejszych, jak współczesnych, krajów i ludów odległych, o jakich autor ma nikłe pojęcie, i z jakimi porozumiewa się z największym trudem. Rozmaite stacje telewizyjne kilka lat temu pokazywały, na przykład reportaż o domach dziecka w Chinach, gdzie masowo one umieraja z głodu i zaniedbania. Zdjęcia były, rzecz jasna, prawdziwe, tyle że nie podano wyraźnie, iż dotyczy to tylko domów dla dzieci niepełnosprawnych lub upośledzonych, gdyż na zdrowe „popyt" jest ogromny. Domy dla dzieci niepełnosprawnych zaś tworzyć zaczęto niedawno, dawniej chłopi nie mający szans na wyżywienie takiej „zbytecznej gęby" zwykle je zabijali zaraz po urodzeniu (jak u nas ,zbyteczne" kocięta). Dopiero teraz, wraz ze wzrostem zamożności społeczeństwa i upowszechnianiem dbałości o prawa człowieka, zakazuje się tego procederu i tworzy publiczne struktury opieki. Nieraz powierza się je ,,ajentom", którzy przy słabej kontroli, starają się maksymalizować zyski kosztem dzieci. Są to zatem koszty i błędy tworzonego od podstaw systemu opieki nad niepełnosprawnymi, nie zaś zamierzone działania władz, które właśnie starają się ich ratować

Wyobraźmy sobie handlarza wietnamskiego ze Stadionu Dziesięciolecia, który coś tam sprzedaje i wyrabia sobie opinie o Polakach na podstawie rozmaitych zasłyszanych wiadomości i wyrywkowych obserwacji (albo wręcz przyjeżdża już z jakimś nastawieniem). W gruncie rzeczy podobna była sytuacja kupców arabskich, tyle że autorzy tu omawiani czerpali jeszcze swą wiedzę z drugiej ręki, z opowieści takich kupców po powrocie do kraju, kiedy nierzadko dawali oni upust swojej fantazji (była to wszak epoka przed telewizyjna i nie można było oglądać takich krajów „,na własne oczy", a wiedza o świecie była wtedy niepomiernie skromniejsza). Dziennikarz nie przygotowany dobrze do odległej podróży i wpadajacy do odległego kraju na tydzień, jest w jeszcze gorszej sytuacji, a przecież bywa, że kraju, o którym pisze, nigdy nawet nie oglądał i dysponuje tylko przypadkowymi wiadomościami wyrwanymi z tamtejszego kontekstu społeczno-politycznego, nadajacego nierzadko zupełnie inny sens opisywanym faktom. Jeden sobie radzi lepiej, a inny gorzej, tym bardziej jeśli redakcja ma określone „polityczne zamówienia" i wręcz nie chce opisów wiernych realiom, jeśli tylko zaprzeczaja one ideologicznym założeniom. Niestety ich obecność wydaje się zjawiskiem ponad ustrojowym. Rozumiejąc naturę tych zafałszowań, będzie nam łatwiej dostrzec je i w omawianych opisach arabskich.

Przy przedstawianiu odległych społeczeństw obserwator zwykle bowiem relacjonuje ich rzeczywistość przez pryzmat swoich wierzeń, przekonań i uprzedzeń. Autor arabski odnotowuje, na przykład, że „Chińczycy prawdziwej religii nie mają" (to jest islamu, s. 61), a wierzenia i kulty zapożyczyli z Indii (co jest prawdziwe tylko w odniesieniu do buddyzmu) 
i wiąże się z traktowaniem Indii jako źródła wszelkiej mądrości. Wspomina o posągach Buddy (uderzających dla muzułmanina) i obcej mu wierze w reinkarnację. Znajdziemy też tam obszerną dyskusję (w duchu arabacentrycznym) o prorokach Bliskiego Wschodu, znanych rzekomo Chińczykom. Podobnie zresztą opisywali Chiny i europejscy misjonarze, tyle że ze swojej perspektywy.

W tych interesujacych tekstach znajdujemy też pierwsze wzmianki o używaniu przez Chińczyków porcelany i herbaty. Autor odnotowuje również, że Chińczycy są dorodni, urodziwi i wysocy (co zadziwia w opisie Kantończyków, zwykle skromniejszej postury niż Chińczycy z Północy). Porównując Chiny i Indie autor stwierdza, że te pierwsze są czystsze, piękniejsze i zdrowsze, nie ma też tam pustkowi, gdyż wszędzie są pola uprawne i osady. Wspomina się też, że w Chinach nie ma żebrzących kalek, tak licznych w Indiach.

W Dodatku znajdujemy szczegółowe opisy wykonywania kary śmierci bez rozlania krwi skazanego (co ułatwić miało mu szybką reinkarnację, a zatem było uznawane za jej „miłosierny" rodzaj, mimo cierpień skazańca). Autor zachwyca się też systemem sądowniczym, który wyraźnie go zafascynował (,sposób w jaki w Chinach władzę sądowniczą sprawowano był jedną z rzeczy podziwu największego godnych, jako i wielki autorytet sędziów tak dobranych, że nikt co do ich wiedzy, prawości, prawdomówności, sprawiedliwości w okolicznościach wszelkich, bezstronności bez względu na wysokie stanowiska, dbałości o dobra materialne ludzi małych i słabych i o inne wszystkie sprawy, wątpliwości nie miał", s. 80-1). Chińskie źródła są tu znacznie bardziej krytyczne, lecz podróżników arabskich musiała niewątpliwie zadziwiać rozbudowana machina biurokratyczna wymiaru sprawiedliwości, na czele $z$ cesarzem, i jej skuteczność

Podobnie zdumiewał ich system rejestracji prostytutek, wpisywanych do oddzielnych ksiąg ludnościowych, i okładanie ich podatkami od ich „działalności zawodowej". Wspomnieć można, że autor zna tylko te trudniące sie na ulicach, i najwidoczniej nie wie o rozbudowanym systemie domów publicznych, czy najelegantszych i bogatych heterach. Odnotowuje on także istnienie sprawnej poczty cesarskiej do przekazywania oficjalnych dokumentów i organizację rodową społeczeństwa.

W sumie więc, mimo rozmaitych wiadomości bałamutnych (jak, na przykład, o braku palm, co może odnosić się tylko do daktylowych), te opisy arabskie są bardzo interesujące i cenne dla historyka. Pokazują też one wyraźnie, że podróżnikom z Bliskiego Wschodu Chiny jawiły się wówczas jako kraj znacznie wyżej rozwinięty. Wątki takie pojawiają się często. „Bardziej biegłych w sztuce malarstwa i kunsztownego rzemiosła nad Chińczyków, pośród wszystkich ludów przez Boga stworzonych, nie znajdziesz, nikt ich nie prześcignie!", czytamy tam, na przykład (s. 70).
Jedynym poważnym mankamentem tej książki jest bardzo szczupła liczba, i to ułamkowych, odniesień historycznych, czy objaśnień. Tak więc czytelnik nie dowie sie, co jest faktem prawdziwym, a co zmyśleniem. Nawet w kwestii tak elementarnej jak nazwy geograficzne występują trudne do objaśnienia potknięcia. Ówczesna stolica Chin - nazywana przez Arabów Humdan po chińsku wówczas zwana Chang'an (dzisiejsze sławne miasto Xi'an) w przypisach identyfikuje się jako: Si-ngan-fu lub Singanfu (według innej transkrypcji Hsi-an-fu, s. 66, 133). Bierze się to stąd, iż autor przekładu nie używa stosowanej dziś powszechnie transkrypcji pinyin, lecz rozmaite dawniejsze, angielskie lub francuskie, zależnie z jakiej literatury korzystał. Przy nazwach geograficznych wprowadza to chaos bardzo utrudniajacy korzystanie z tej pracy. W odniesieniu do Azji Południowo-wschodniej chaos ten jest jeszcze większy, a często wręcz trudno się zorientować jakiego kraju opis dotyczy.

Gdy Autor wychodzi poza znane mu sprawy filologii arabskiej (nie wypowiadam się o nich zupełnie ze względu na brak kompetencji) zdarzają mu sie przykre potknięcia. Na przykład, przy analizie arabskiej nazwy dla herbaty pisze, że rosyjska nazwa ćaj pochodzi z kantońskiego dialektu, w którym ma ona formę $c^{\prime} a(s$. 55, w transkrypcji pinyin - cha). Otóż po pierwsze, ,nie jest to tylko wymowa tego dialektu, lecz także dialektów północnych (i obecnego ,języka ogólnonarodowego"). Rosjanie zapożyczyli ją właśnie z Północy, a pochodzi ona od dwu słów cha ye ,liście herbaty". Natomiast arabska nazwa herbaty .̌́ah może mieć związek z dialektem kantońskim, gdyż w precyzyjnych zapisach fonetycznych, wyraźniej niż w dialektach północnych, występuje w nim element zbliżony do ś (patrz: Li Zhenhua, Zhou Zhangji, gujin yin biao - Lista wymowy hieroglifów chińskich od starożytności do dzisiaj, Zhonghua Shuju, Beijing 1993, s. 309). Nie dysponując precyzyjnymi listami wymowy tego słowa w dialekcie kantońskim w X w. moge tylko przypuszczać, iż w omawianym okresie ta spółgłoska szczelinowa również występowała, może nawet wyraźniej, o czym świadczyć może właśnie zapis arabski. W każdym razie sprawa wymagałaby dodatkowych studiów, a $\mathrm{z}$ pewnościa współczesne formy wymowy nie mogą być podstawą rekonstrukcji językowych odnoszących się do $\mathrm{X}$ w. Niestaranna redakcja przypisów utrudnia korzystanie $\mathrm{z}$ nich (na przykład, odsyłacze podają numer przypisu, w jakich dana kwestia jest omawiana bardziej szczegółowo, ale bez wskazania z którego z rozdziałów, i trzeba je żmudnie odszukiwać).

Mimo pewnych mankamentów redakcyjnych, jakich można by wymienić więcej, jest to fascynująca praca, nie tylko bardzo użyteczna dla historyka, lecz interesująca i dla miłośnika historii. 